\title{
原著論文
}

\section{講義および問題解決型学習の双方で総義歯学を履修した 学生の学習効果に関する比較検討}

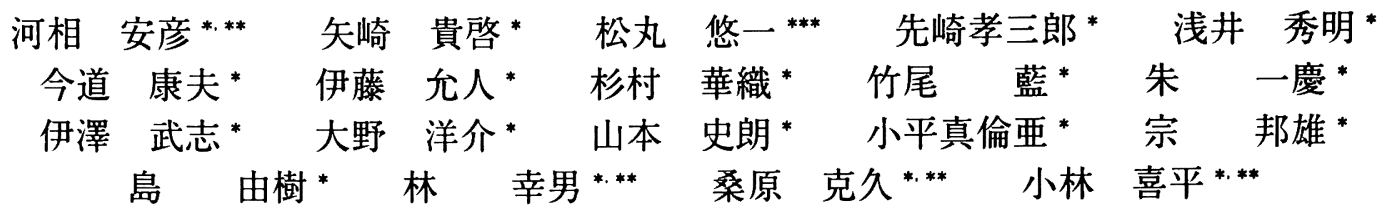

Comparative Analysis of Learning Effect for Students who Experienced both Lecture-based Learning and Problem-based Learning in a Complete Denture Course

Kawai Yasuhiko***, Yazaki Takahiro*, Matsumaru Yuichi*** Senzaki Kozaburo*, Asai Hideaki*, Imamichi Yasuo*, Ito Mitsuto*, Sugimura Kaori*, Takeo Ai*, Shu Kazuyoshi*, Izawa Takeshi*, Ohno Yosuke*, Yamamoto Shiro*, Kodaira Maria*, So Kunio*, Shima Yuki*, Hayashi Yukio**** Kuwahara Katsuhisa ${ }^{* * *}$ and Kobayashi Kihei****

\section{歯科補緅学的意義}

講義形式型学習 (LBL) と問題解決型学習 (PBL) での学習効果の比較は PBL 導入にあたり, 意義深い根拠となる. そこで総義歯学の履修にあたり LBL と PBL とを経験した学生の学習態度, 臨床推理能力, 授業および教員の評価を 比較・検討したところ PBL が及ほす効果が有意に高い結果が得られた．学部教育で PBL 総義歯学へ導入すること は，臨床実習または卒後の臨床へ有意義な効果を与える可能性が示唆された.

抄 録

目的：本研究の目的は総義歯学の授業で講義型学習（以下 LBL）と問題解決型学習（以下 PBL）双方 を経験した学生の自己学習および臨床推理能力に関する教育効果と授業・教員に対する評価の両教育形 式間での比較検討である.

方法：総義歯学の授業を平成 15 年度入学の学生に, 平成 17 年度 3 年次前期に LBL, 平成 18 年度 4 年 次前期にPBLにて行った. PBLは 5 回にわたり, 毎回 1症例についてグループディスカッションを行い, グループによるまとめを 2 回, 個人レポートを 2 回および全体発表を 1 回という予定で進行した. 全体 発表終了後, 教育効果および授業・教員に関する 27 項目のアンケートを行った．因子分析により質問 項目の類型を行い，各質問項目について LBL および PBL の比較を行った（Paired-t）.

結果：因子分析より質問項目は 4 因子に類型された. LBL と PBL との間で「学習態度」について 7 項目

${ }^{*}$ 日本大学松戸歯学部顎口胿義歯リハビリテーション学講座

${ }^{* *}$ 日本大学松戸歯学部口腔科学研究所

${ }^{* * *}$ 日本大学大学院松戸歯学研究科歯学専攻

* Department of Gnatho-Oral Prosthetic Rehabilitation, Nihon University School of Dentistry at Matsudo

${ }^{* *}$ Institute of Oral Science, Nihon University School of Dentistry at Matsudo

${ }^{* * *}$ Nihon University Graduate School of Dentistry at Matsudo

受付 : 2006 年 11 月 24 日/受理 : 2007 年 6 月 1 日

Received on November 24, 2006/Accepted on June 1, 2007 
中 4 項目,「臨床推理能力」について全項目,「授業内容」について 7 項目中 5 項目,「教員評価・そのほか」 について 6 項目中 2 項目，合計 27 項目中 18 項目（66.6\%）でPBL が有意に高い值を示した.

結論：PBL は LBL に比べ自己学習および臨床推理能力の教育効果の向上に極めて有効で, 授業に関す る評価も有意に高かった，一方，同様の授業を受けることに学生は後向きで，消極性解消法の検討が必 要であると示唆された.

和文キーワード

PBL，臨床推理，グループディスカッション，SOAP，補綴歯科医学教育

\section{I. 緒 言}

問題解決型学習 (problem-based learning, 以下 PBL）は，1970 年代に McMaster 大学にて初めて医 学教育へ応用されて以来, 講義形式型学習 (lecturebased learning，以下 LBL）に対比される医学教育に おける学習法として発展し, 多くの教育現場で導入の 試みがなされ ${ }^{1 \sim 4)}$ ，その実施に関する評価・点検の報 告が多く見られる ${ }^{1.5 .6)}$. しかし, PBLが習得すべき 知識・技能・態度のどのような領域に有効であり， どのような教育分野に適応可能かという判断基準を得 るには，海外で報告されているようにLBL と PBL と を別々に受けた学生について ${ }^{7 \sim 9)}$ もしくは，同じ学年 の学習者を無作為に振り分けた場合の ${ }^{10.11)}$ 学習効果 について比較することが必要である．本邦では教育倫 理の観点から無作為化などは現状では難しく，また LBL と PBL とを同時に学習するカリキュラムプラニ ングは時間の制約や，教員確保の点から難しく，その ような報告は少ない ${ }^{4)}$.

本学ではカリキュラム改革に伴い平成 17 年 4 月よ り 9 月まで統合講義「歯と歯周組織の疾患」の 1 科目 として有床補緅学の講義が総義歯学および局部床義歯 学の構成で 3 年次を対象にLBL にて行われた。 その 後, カリキュラム再編に伴い有床補緅学を履修し進級 した学生が， 4 年次で系統講義として総義歯学の履修 を平成 18 年 4 月より 9 月まで行うことを受け，平成 17 年度は LBL で授業を行ったのに対し，平成 18 年 度は一部 PBL での授業計画を立案し実施に移した。 そこで総義歯学に関して LBL と PBL 双方を受講した 学生が,「自己の学習態度」および「症例を通じた臨
床推理能力」の向上 ${ }^{12)}$ を中心とした自己評価を LBL および PBL 双方について行い，学習方法の違いによ る学習効果の間に差がないという帰無仮説を検証し、 興味ある知見を得ると同時に今後のカリキュラムプラ ニングに対する示唆を得たので報告する.

\section{II. 研究方法}

\section{1. 授業日程}

PBLの授業日程は赤川ら ${ }^{13)}$ の実施および点検報 告を参考に作成した．15 週間におよぶ日程は，まず LBL で知識領域のブラッシュアップと臨床をより意 識させるために印象採得および咬合採得の動画を供覧 してから PBL へ移行した。 また時間数の減少に対応 するようにPBL と実習をくさび状に配し, 講義内容 また PBL の症例内容が実習の進行と可能な限り連携 するようにした（表 1$)$.

\section{2. 実施方法}

まず教員および学生に PBL の意味，目的，実施方 法をそれぞれ別に十分説明した ${ }^{14)}$. 概論として「症 例を入り口にして医学を学ぶ」「学習者の自発性を引 き出す」「学習者は到達目標に向かって自学自習」を 行う重要性を説明し，知識という「肉」を与えられる のではなく，知識を得る「狩猟法」を経験することが 重要であることを強調した．そして少人数でのグルー プ討論を通して課題を見つけ，各々が自宅に持ち帰り 自学自習を行うよう促した，教員には「細かな知識を 与えないこと」と「自発性を引き出す促進役に努める こと」を強調した，各グループは 10 名とし, 教員 1 名を配置した。 
表 1 Agenda 日程表

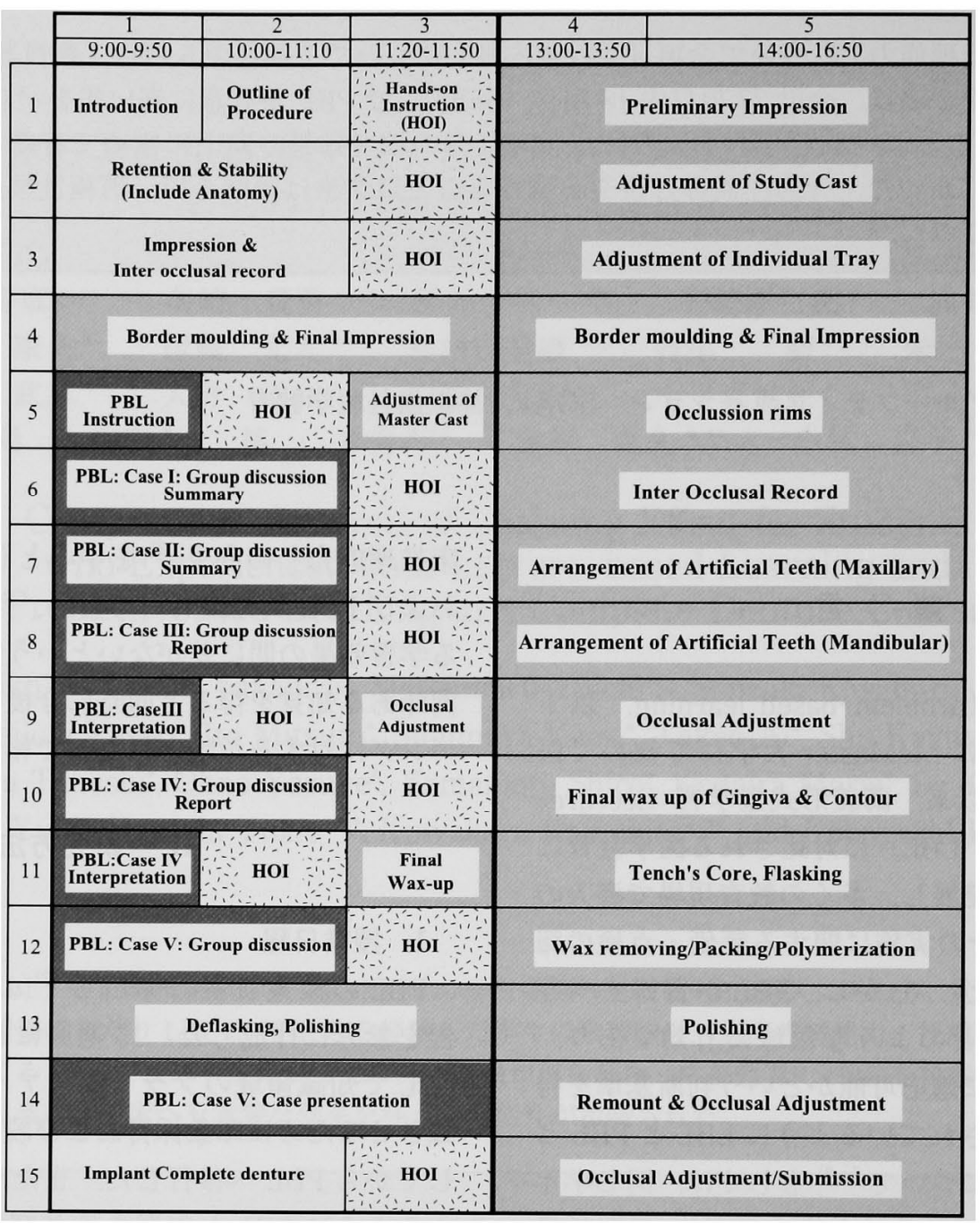

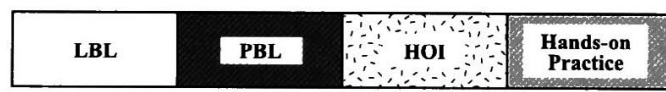

提示する症例には患者の主訴，医科および歯科的既 往歴, 症例およびX線写真による現症，患者の希望 などが含まれている，学生にはこれらから(1)問題点を 抽出し，(2)考えられる解決策を調べ, (3)症例への適応 の可否を判断し，(4)治療計画を立案するという流れに 沿って，学習を行うよう促した ${ }^{12)}$. 一連の思考の整 理は，グループ内で基準化を図るために SOAP（S : Subjective ·主訴, $\mathrm{O}:$ Objectives · 観察記録, A : Assessment・評価・診断, P : Plan・計画）による経 過記録の整理法を提示し，それに沿って行うよう方向 づけた ${ }^{15.16)}$.

期間中に 5 回のグループディスカッションを行い, 毎回 1 症例, 合計 5 症例を提示した. 症例 1 および 2 は全グループ共通症例とし問題点の抽出, 計画立案の
グループディスカッションを行い, その日にグルー プ単位でまとめを提出してもらった。 これはグルー プのアイスブレーキングおよびディスカッションの円 滑化を図ると同時に教員サイドの指導方法の標準化を 図る目的があった．各グループ共通症例 3 および 4 は 同じくグループディスカッションの結果を基に個人単 位でレポートを作成し， 1 週間後に提出をしてもらっ た.これにより自己および自宅学習の向上を図った. レポート提出日に, 提示症例の問題点の抽出, 解決法 および治療計画立案の考え方に関する講義を行い, 自 己学習の復習ができるよう配慮した，第 5 症例ではグ ループごとに異なる症例を各グループの教員が提示 し，学生が自主的に資料の作成を行い，全教員および 学生参加で Power Point を用い, 12 症例の発表を行っ 
た. なお,グループディスカッションではリーダー, レコーダー，レポーターを決めるよう指示し，提示症 例ごとに役割を変えるよう指示した。

\section{3. 評価方法および解析}

教育効果および授業・教員に関する 27 項目の質問 票を過去の報告 ${ }^{4.13)}$ にならい作成し（表 2)，グルー ブ発表終了後 120 名の学生を対象に同じ質問項目を用 い, 3 年次で行った LBL と 4 年次で行った PBLにっ いてそれぞれ無記名で回答を求めた.

解析は質問項目の属性を明らかにする目的で因子分 析を行った，その際，固有值はカイザーガットマン基 準を用い 1 以上を因子として取り込んだ後にバリマッ クス回転を行なった後，因子の解釈を行い，質問項目 を分類した.「LBL と PBL との間で各学習者の評価 に差はない」という帰無仮説を検証するために，各質 問項目について LBL と PBL との間で Paired-t 検定 を行った。なお統計解析には $\mathrm{Stata}^{\mathrm{TM}}$ version $7.0(\mathrm{Col}-$ lege Station, Texas）を用い, 有意確率は $5 \%$ とした.

\section{III. 結 果}

\section{1. 回収率}

120 名に配布を行い 114 名より回収された（回収率 $95 \%)$.

\section{2. 質問項目の属性}

因子分析の結果, 質問項目は 4 因子に類型された. 各因子について第 1 因子を「自己の学習態度（7 項 目)」，第 2 因子を「臨床推理方略（7 項目）」，第 3 因 子を「授業内容 (7 項目)」, 第 4 因子を「教員評価（5 項目)」と「そのほか (1 項目)」と解釈した（表 3).

\section{3. 各質問項目の差の検定}

図 1 および 2 に各項目の LBL および PBL の評価の 比較と有意性を示す。「学習態度」（図 1）について7 項目中 4 項目,「臨床推理能力」（図 2) について全項 目,「授業内容」（図 3）について 7 項目中 5 項目, 「教 員評価」（図 4) について 5 項目中 2 項目で LBL に比 較し PBL のほうが有意に高い値となり，27 項目中 18 項目 (66.6\%) でPBL の有用性を示した.

\section{IV. 考察}

\section{PBL の実施について}

従来の LBL は知識の伝達に重点を置くことから， 「病名または診断」に重きが置かれ「症状・症候」が それに続く傾向にあるといわれてきた ${ }^{14)}$. 総義歯学に 転じてみると, LBL は総義歯の作製段階について順 を追って系統的に知識を習得させるには非常に適して いると考えられる一方で,「なぜこの段階でこの処置 が必要なのか」などを考えさせる機会が得にくいと思 われる. 特に, 患者の背景を中心とした総義歯治療計 画の立案や，臨床で高頻度に遭遇する総義歯装着後の 訴えに対する傾聴, 問題点の整理, 解決策の立案, 実 施という思考の訓練は LBL では習得しにくいと考え られる。一般に, PBLはこのような問題の解決法を 学習するには適切な方法であると考えられており，「臨 床推理能力」全項目について学生自身が PBLでの習 得が有意であると認めた今回の結果より, 総義歯学に おいても極めて効果的であることが明らかになった.

実施に当たって問題解決能力を養うために重要な教 材が症例シナリオの提示である. 赤川 ${ }^{1)}$ は症例の提 示数を PBL 初年度の 2 症例から次年度には 4 症例へ と倍増している.これは症例数が少ないと一つの症 例に組み込む問題が多くなり症例シナリオが複雑にな るのを防ぐためとしている. 我々は今回の実施に当た り，この点を参考とし，初年度から提示数を 5 症例と し，1 症例に含まれる問題点は一つに限定された。 そ の結果, 学生は問題点抽出の理解が明瞭にでき, 解決 法に向けた調べ学習に十分時間を費やすことができ た。 また症例に関するまとめの提出および全体発表の ための準備が中途で終了することなく，提出物または 発表成果へと結びつけられていた。一方, 問題抽出が 早い分グループ討論が短く, 学生が数名に分かれて行 う調べ学習の時間が長くなり, PBLの主題の一つで あるグループ全体での討議の時間が隇ってしまった感 がある.これは，LBLで一定レベルの知識を習得し ている本報告の学生にはやや内容が容易であったとも 考えられる. 今後 PBLのみで履修を行った場合の検 討を行い, 最適な提示症例数および各症例で抽出すべ き問題点の数について総括を加え, 結論を導く必要が あると考えられる. 
表 2-a Questionnaire on educational effect, lecture and tutors assessment (English) 教育効果㧍よび授業・教員に関する質問票（英語）

Plaese circle one answer that you most think it appropriate

\begin{tabular}{|c|c|c|c|c|c|}
\hline & \\
\hline & $\begin{array}{l}\text { Totally } \\
\text { agree }\end{array}$ & Agree & Neutral & Disagree & $\begin{array}{c}\text { Totally } \\
\text { disagree }\end{array}$ \\
\hline 1 Class contents were well prepared & 5 & 4 & 3 & 2 & 1 \\
\hline 2 The lecture composition was systematic & 5 & 4 & 3 & 2 & 1 \\
\hline 3 The class followed the time schedule & 5 & 4 & 3 & 2 & 1 \\
\hline 4 Important issues were emphasized & 5 & 4 & 3 & 2 & 1 \\
\hline 5 Difficulty of work was appropriate & 5 & 4 & 3 & 2 & 1 \\
\hline 6 Atmosphere was easy to ask questions & 5 & 4 & 3 & 2 & 1 \\
\hline 7 Felt the enthusiasm of the tutors & 5 & 4 & 3 & 2 & 1 \\
\hline 8 Tutors explanation was comprehensible & 5 & 4 & 3 & 2 & 1 \\
\hline 9 Useful in the future carrier & 5 & 4 & 3 & 2 & 1 \\
\hline 10 Prepared well for the class & 5 & 4 & 3 & 2 & 1 \\
\hline 11 Able to search appropriate references and books & 5 & 4 & 3 & 2 & 1 \\
\hline 12 Read sufficient books or literature during the period & 5 & 4 & 3 & 2 & 1 \\
\hline 13 Time for home study has increased & 5 & 4 & 3 & 2 & 1 \\
\hline 14 Self study was substantial & 5 & 4 & 3 & 2 & 1 \\
\hline 15 My competence has increased & 5 & 4 & 3 & 2 & 1 \\
\hline 16 Motivation for medical care was stimulated & 5 & 4 & 3 & 2 & 1 \\
\hline 17 The study effect of the class was high & 5 & 4 & 3 & 2 & 1 \\
\hline 18 Acquired clinical knowledge & 5 & 4 & 3 & 2 & 1 \\
\hline 19 Could understand how to grasp the subjective & 5 & 4 & 3 & 2 & 1 \\
\hline 20 Could understand how to grasp the objectives & 5 & 4 & 3 & 2 & 1 \\
\hline 21 Could understand how to draw an assessment & 5 & 4 & 3 & 2 & 1 \\
\hline 22 Could understand how to form treatment planning & 5 & 4 & 3 & 2 & 1 \\
\hline 23 Made study issue systematic by yourself & 5 & 4 & 3 & 2 & 1 \\
\hline 24 Understood the way of self learning & 5 & 4 & 3 & 2 & 1 \\
\hline 25 Understood the goal of class & 5 & 4 & 3 & 2 & 1 \\
\hline 26 Set a high evaluation on this class & 5 & 4 & 3 & 2 & 1 \\
\hline 27 Would like to take this type of class again & 5 & 4 & 3 & 2 & 1 \\
\hline
\end{tabular}

表 2-b Questionnaire on educational effect, lecture and tutors assessment (Japanese) 教育効果および授業・教員に関する質問票（日本語）

各項目についてあてはまるものに1つ○印を付けてください

\begin{tabular}{|c|c|c|c|c|c|}
\hline & \multicolumn{5}{|c|}{ 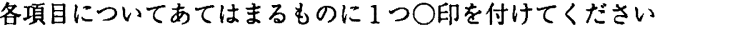 } \\
\hline & そう思う & やや思う & $\begin{array}{l}\text { どちらとも } \\
\text { いえない }\end{array}$ & $\begin{array}{c}\text { あまり } \\
\text { 思わない }\end{array}$ & そう思わない \\
\hline 1 授業内容がよく準備されていると感じましたか & 5 & 4 & 3 & 2 & 1 \\
\hline 2 授業の構成はシステマティックであると感じましたか & 5 & 4 & 3 & 2 & 1 \\
\hline 3 授業は時間どおりに行われましたか & 5 & 4 & 3 & 2 & 1 \\
\hline 4 重要事項が強調されていましたか & 5 & 4 & 3 & 2 & 1 \\
\hline 5 学生にとって適切な難易度でしたか & 5 & 4 & 3 & 2 & 1 \\
\hline 6 質問しゃすい雾囲気でしたか & 5 & 4 & 3 & 2 & 1 \\
\hline 7 教貝の熱意が感じられましたか & 5 & 4 & 3 & 2 & 1 \\
\hline 8 教貝の説明は理解しやすかったですか & 5 & 4 & 3 & 2 & 1 \\
\hline 9 将来役立つと思えますか & 5 & 4 & 3 & 2 & 1 \\
\hline 10 授業の予習をした & 5 & 4 & 3 & 2 & l \\
\hline 11 適切な參考図書・文献を探せた & 5 & 4 & 3 & 2 & 1 \\
\hline 12 期間中に参考図書・文献をよく読んだ & 5 & 4 & 3 & 2 & 1 \\
\hline 13 自宅学習の時間が增えた & 5 & 4 & 3 & 2 & 1 \\
\hline 14 自身の学習充実度は高かった & 5 & 4 & 3 & 2 & 1 \\
\hline 15 自分自身が成長したと感じた & 5 & 4 & 3 & 2 & 1 \\
\hline 16 医療に対する意欲が刺激された & 5 & 4 & 3 & 2 & 1 \\
\hline 17 授業の学習効果は高かった & 5 & 4 & 3 & 2 & 1 \\
\hline 18 臨床的な知識が身につきましたか & 5 & 4 & 3 & 2 & 1 \\
\hline 19 主訴の捕らえ方を理解できましたか & 5 & 4 & 3 & 2 & 1 \\
\hline 20 観察記録の捕らえ方が理解できましたか & 5 & 4 & 3 & 2 & 1 \\
\hline 21 評価・診断の方法が身につきましたか & 5 & 4 & 3 & 2 & 1 \\
\hline 22 治療計画立案の方法が身につきましたか & 5 & 4 & 3 & 2 & 1 \\
\hline 23 学習したことを自分なりに体系化できた & 5 & 4 & 3 & 2 & 1 \\
\hline 24 自己学習の方法が分かった & 5 & 4 & 3 & 2 & 1 \\
\hline 25 この授業の目的・目標とするところが理解できましたか & 5 & 4 & 3 & 2 & 1 \\
\hline 26 この授業は総合的に高く評価できますか & 5 & 4 & 3 & 2 & 1 \\
\hline 27 このタイプの授業をまた受けたいと思いますか & 5 & 4 & 3 & 2 & 1 \\
\hline
\end{tabular}


表 3 The results of factor analysis on questionnaire 質問票の因子分析結果

\begin{tabular}{|c|c|c|c|c|c|}
\hline Items & $\mathrm{I}$ & II & III & IV & Uniqueness \\
\hline Time for home study has increased & 0.76 & 0.28 & -0.33 & 0.10 & 0.18 \\
\hline Self study was substantial & 0.72 & 0.18 & -0.37 & 0.13 & 0.21 \\
\hline Read sufficient books or literature during the period & 0.69 & 0.29 & -0.15 & 0.19 & 0.26 \\
\hline My competence has increased & 0.61 & 0.26 & -0.50 & 0.07 & 0.25 \\
\hline Prepared well for the class & 0.58 & 0.15 & -0.10 & 0.25 & 0.46 \\
\hline Able to search appropriate references and books & 0.52 & 0.42 & -0.39 & 0.16 & 0.26 \\
\hline Made study issue systematic by yourself & 0.46 & 0.31 & -0.48 & 0.33 & 0.24 \\
\hline Could understand how to grasp the objectives & 0.33 & 0.78 & -0.29 & 0.26 & 0.27 \\
\hline Could understand how to draw an assessment & 0.30 & 0.73 & -0.19 & 0.20 & 0.13 \\
\hline Could understand how to grasp the subjective & 0.20 & 0.67 & -0.30 & 0.23 & 0.17 \\
\hline Could understand how to form treatment planning & 0.29 & 0.65 & -0.07 & 0.32 & 0.27 \\
\hline Useful in the future carrier & 0.06 & 0.55 & -0.31 & 0.16 & 0.23 \\
\hline Acquired clinical knowledge & 0.35 & 0.53 & -0.47 & 0.30 & 0.29 \\
\hline Understood the way of self learning & 0.41 & 0.42 & -0.45 & 0.13 & 0.25 \\
\hline Would like to take this type of class again & 0.23 & 0.10 & -0.84 & 0.14 & 0.15 \\
\hline Set a high evaluation on this class & 0.25 & 0.14 & -0.80 & 0.30 & 0.11 \\
\hline The study effect of the class was high & 0.36 & 0.32 & -0.70 & 0.10 & 0.19 \\
\hline Understood the goal of class & 0.15 & 0.46 & -0.67 & 0.13 & 0.16 \\
\hline Class contents were well prepared & 0.22 & 0.25 & -0.57 & 0.45 & 0.22 \\
\hline The lecture composition was systematic & 0.24 & 0.20 & -0.56 & 0.42 & 0.27 \\
\hline Motivation for medical care was stimulated & 0.42 & 0.48 & -0.56 & 0.03 & 0.18 \\
\hline Important issues were emphasized & 0.24 & 0.23 & -0.22 & 0.70 & 0.28 \\
\hline Tutors explanation was comprehensible & 0.25 & 0.17 & -0.24 & 0.64 & 0.34 \\
\hline Felt the enthusiasm of the tutors & 0.15 & 0.38 & -0.37 & 0.60 & 0.17 \\
\hline Difficulty of work was appropriate & 0.00 & 0.35 & -0.34 & 0.50 & 0.35 \\
\hline The class followed the time schedule & -0.02 & 0.34 & -0.07 & 0.46 & 0.51 \\
\hline Atmosphere was easy to ask questions & 0.15 & 0.29 & -0.27 & 0.16 & 0.48 \\
\hline Eigen value & 13.1 & 1.5 & 1.3 & 0.9 & \\
\hline
\end{tabular}

\section{2. 研究方法ならびに結果について}

PBL を導入し，その評価を行った報告は比較的多 く認められる ${ }^{1.2 .6)}$ 一方で, 海外において報告されて いるようにLBL と PBL 形式を異なる入学年での比 較 ${ }^{7 \sim 9)}$ ，同一学年を無作為にLBL またはPBLに振り 分けての比較は ${ }^{10.11)}$, 本邦においては少ない ${ }^{4)}$. 特に, 同一学生を対象とした評価は補綴学では報告がない。 著者らは，カリキュラム改革に伴い同一学生に LBL および PBL 双方の形式で総義歯学を履修させるこの 機会に，それらの教育効果をPBL の主眼である「自 己の学習態度」および「症例を通じた臨床推理能力」 の向上を中心とした評価を比較し，教育効果の違いを 明らかにするための研究計画を立案した。

結果を考察すると, 自己の学習態度に関しては「適 切な参考図書・文献を探せた」，「期間中に参考図書 -
文献をよく読んだ」「「自身の学習充実度は高かった」, 「学習したことを体系化できた」などに自発的な学習 態度において有意な改善が認められたのは，グルー プ学習を通じた役割分担による影響があると考えら れた，一方で，「授業の予習をした」，「自宅学習の時 間が増えた」については改善の兆しが認められなかっ たことはグループ学習を離れ，個人での学習習慣を変 えることが容易でないことを表していると同時に，グ ループ学習での学習で十分対応出来たためではないか とも考えられた.

臨床推理方略については全項目において有意な改善 が見られた. PBL 第 2 の主眼である「症例を通じた 臨床推理能力」の向上は「将来役立つと思える, 臨床 的な知識が身についた」という質問項目の有意な改善 より十分に達成できたと考えられた。そその方略として 


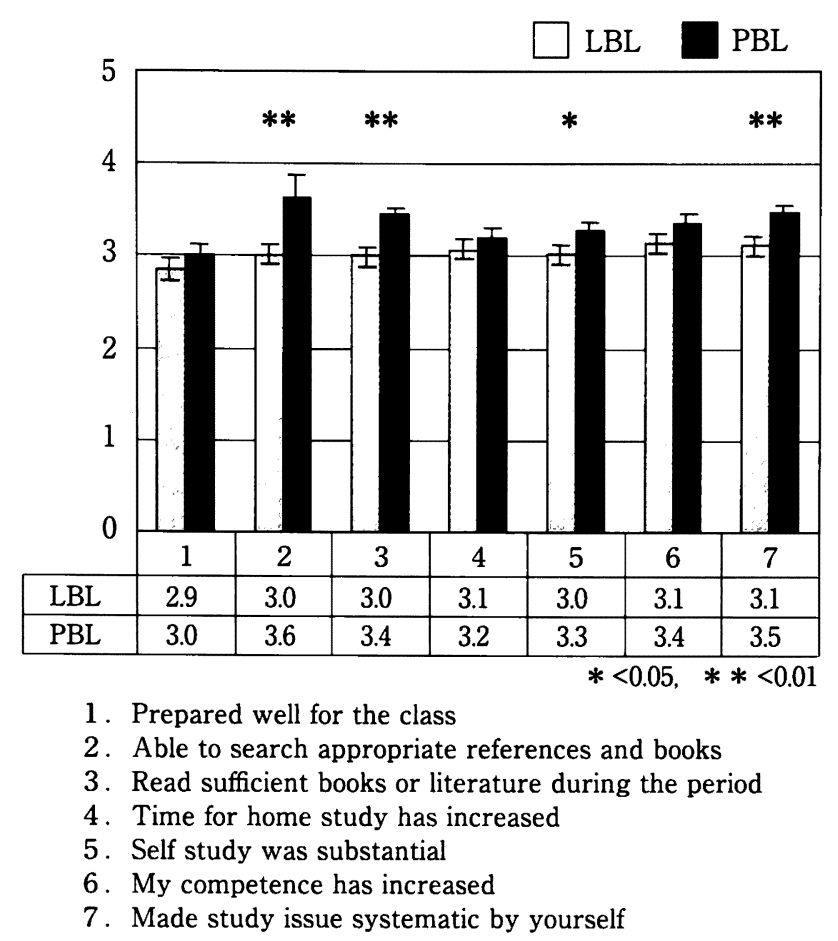

図 1 Comparison of self assessment on study attitude between LBL and PBL

LBL およびPBLにおける学習態度に対する自己評価の 比較

提示したSOAPによる思考過程の整理法が十分に理 解され，その点が「自己学習の方法が分かった」とい うことにつながったと考えられる。

授業内容については「授業内容がよく準備され，構 成はシステマティックであった」という授業そのもの の進め方についての評価が有意に改善されていた。こ れは，実施にあたり学生および教員に目的と方略を明 示していること，また時間構成が明瞭なことに起因し ていると考えられ，「この授業の目的・目標とが理解 できた」が有意に改善されているのはその表れである と考えられる．本学では LBL においても到達目標お よび行動目標は明示されているが，学生にとって自 発的な PBL を実施する場合にその重要性をより身近 に感じた表れではないかと思われる. 今後も実施に当 たってこの点を十分に明瞭にすることは必須であると 考える.「医療に対する意欲が刺激された」は症例を 通じて学ぶという PBLの目的が具体化されたものの 一つで, この点が改善されたのは評価されるべき点 であると思われる。一方，「この授業は総合的に高く 評価できる」,「このタイプの授業をまた受けたい」

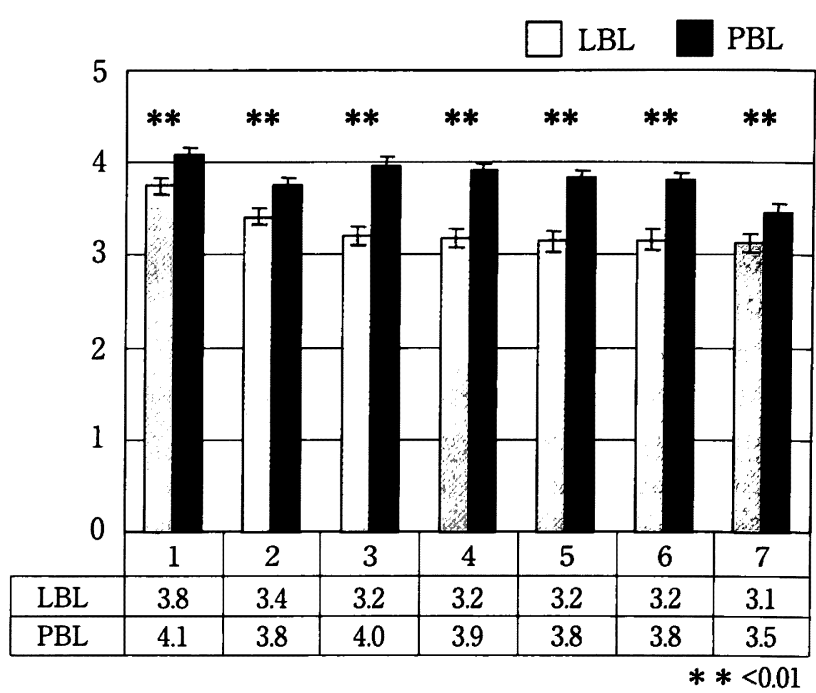

1. Useful in the future carrier

2. Acquired clinical knowledge

3 . Could understand the how to grasp the subjective

4. Could understand the how to grasp the objectives

5. Could understand the how to draw the assessment

6 . Could understand the how to make the treatment plan

7 . Understood the way of self learning

図 2 Comparison of self assessment on clinical inference ability between $\mathrm{LBL}$ and PBL

LBL および PBL における臨床推理能力に対する自己評 価の比較

は LBL との間で有意の差は認められなかった.これ は他の報告と同様であり ${ }^{4)}$ その理由としては本年度 PBL を導入した学科目が他にもあり，それによる学 生の慣れが考えられる ${ }^{2)}$. また PBL の受講を希望し た学生は十分な能力を有する学生であったという報 告 ${ }^{7)}$ から, PBL を本格導入し, 成功させるためには, 学生の資質および情操を入学後早期に高める教育の機 会を積極的に設定 ${ }^{17)}$ することが重要ではないかと考 えられる。

教員評価の項の「重要事項が強調されていた」,「教 員の説明は理解しやすかった」について有意に改善さ れていたのは，教員との接触が小グループになったこ とより，近くなったためと思われる。またSOAPに よる標準化 ${ }^{15,16)}$ が教員および学生に共通言語として 理解しやすい結果を生んだことも考えられた。一方， 他の項目については有意差を認めなかったことから学 習形式による教員評価への影響は少ないことが明らか になった。

以上の結果は，LBL と PBL の実施時期の間におよ そ 1 年間の時差が存在し, 回答者にとって, PBLの 


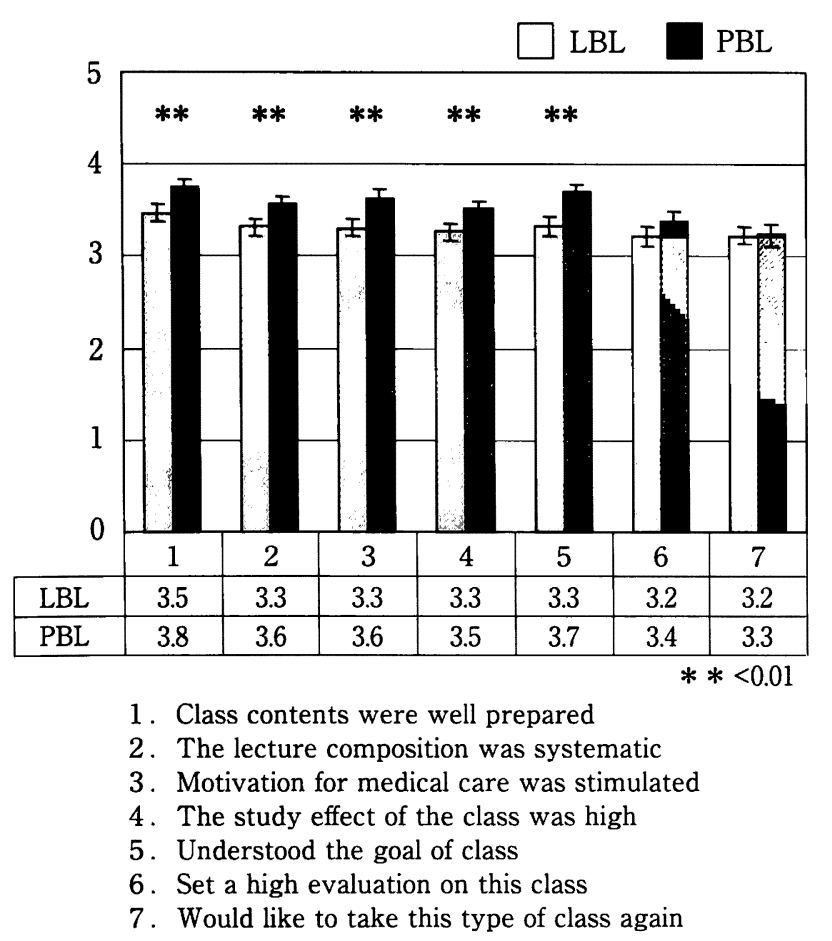

図 3 Comparison of assessment on class contents between LBL and PBL

LBL および PBL における授業内容に対する評価の比較

方により大きな印象を覚えている可能性はあるもの の, LBL との比較を同一の学生で行った点は十分意 義深いものと考える. 今後は PBL, LBL 双方を受講 した履修者の臨床実習から卒後における評価を行い, LBL のみで履修した学生と対比し，その結果よりカ リキュラム改革を継続し, 教育の質の向上を積み重ね て行く必要があると考える.

\section{V. 結 論}

1. PBL は LBL に比べ自己学習および臨床推理能力 の教育効果向上に極めて有効であった.

2. 授業に関する評価も有意に高かったが，同様の授 業を受けることに学生は消極的であり，PBL 全体 の実施方略の見直しが必要と示唆された.

\section{文献}

1）赤川安正.「問題解決能力をいかに引き出すか一その実践 例」総義蒾学における問題解決型学習の実践とその評価. 日歯教誌 $14: 67-73,1998$.

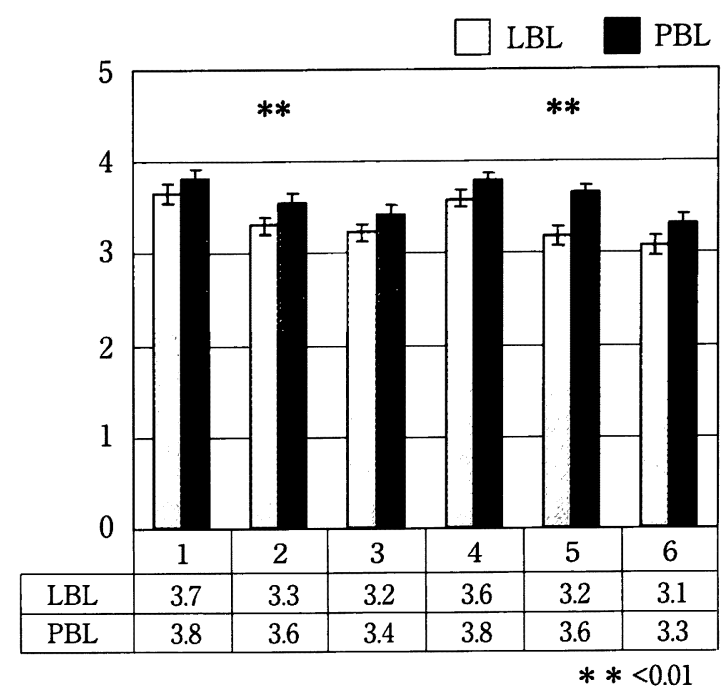

1. The class followed the time schedule

2. Important issues were emphasized

3. Difficulty of work was appropriate

4. Felt the enthusiasm of the tutors

5. Tutors explanation was comprehensible

6. Atmosphere was easy to ask questions

図 4 Comparison of assessment on tutors between LBL and PBL

LBL および PBL における教員に対する評価の比較

2）佐藤裕二，積田正和，北川 昇. 高齢者歯科学における 2 年間の PBL チュートリアルの実施と点検評価. 日歯教誌 $20: 41-45,2004$.

3）葛城啓彰, 五十嵐勝, 長田敬五ほか. 日本歯科大学新潟 歯学部におけるPBL テュートリアルの導入. 日歯教誌 $21: 279-291,2005$.

4）道脇幸博，南雲正男． PBL を応用したグループ学習と症 例発表による自己学習の促進一講義形式との比較一. 日 歯教誌 $22: 9-16,2006$.

5）佐藤裕二，津賀一弘，赤川安正. 歯科医学教育における PBL の実践一部分床義歯学における 7 年間の点検評価. 医学教育 $33: 359-360,2002$.

6）有田正博，津田緩子，槙原絵理ほか，予備登院中に実施 した補緅臨床に関する問題解決型学習の評価. 九州歯会 誌 $59: 173,2005$.

7) Cariaga-Lo LD, Richards BF, Hollingsworth MA et al. Non-cognitive characteristics of medical students : entry to problem-based and lecture-based curricula. Med Educ 30 : 179-186, 1996.

8) Richards BF, Ober KP, Cariaga-Lo L et al. Ratings of students' performances in a third-year internal medicine clerkship : a comparison between problem-based and lecture-based curricula. Acad Med 71 : 187-189, 1996.

9) Login GR, Ransil BJ, Meyer $M$ et al. Assessment of preclinical problem-based learning versus lecture-based 
learning. J Dent Educ 61 : 473-479, 1997.

10) Antepohl W. Herzig S. Problem-based learning versus lecture-based learning in a course of basic pharmacology : a controlled, randomized study. Med Educ 33 : 106-113, 1999.

11) Herzig S, Linke RM, Marxen B et al. Long-term follow up of factual knowledge after a single, randomised problem-based learning course. BMC Med Educ $3: 3,2003$.

12) Vernon DT, Blake RL. Does problem-based learning work? A metaanalysis of evaluative research. Acad Med $68: 550-563,1993$.

13）赤川安正，佐藤裕二，津賀一弘ほか. 歯科医学教育にお ける Problem-based learningの試み一総義歯学における 3 年間の実施と点検評価一. 日歯教誌 $13: 17-22,1998$.

14）相馬正義. PBL テュートリアルシステム. 日大医誌 64 : 337-339, 2005.
15) Rethman J. Clean up your records with SOAP. S (subjective findings), $\mathrm{O}$ (objective findings), A (assessment), $\mathrm{P}$ (plan). Dent Today $14: 80,1995$.

16) Donnelly WJ. Viewpoint : patient-centered medical care requires a patient-centered medical record. Acad Med $80: 33-38,2005$.

17）岡野友宏. 歯科医学教育における PBL テュートリアルの 現況. 日歯教誌 別冊：94-97，2006.

著者連絡先 : 河相 安彦

于 271-8587 千葉県松戸市栄町西 2-870-1

TEL : 047-360-9378

FAX : 047-360-9376

E-mail : kawai.yasuhiko@nihon-u.ac.jp 


\title{
Comparative Analysis of Learning Effect for Students who Experienced both Lecture-based Learning and Problem-based Learning in a Complete Denture Course
}

\author{
Kawai Yasuhiko***, Yazaki Takahiro*, Matsumaru Yuichi***, Senzaki Kozaburo*, Asai Hideaki*, \\ Imamichi Yasuo*, Ito Mitsuto*, Sugimura Kaori*, Takeo Ai*, Shu Kazuyoshi*, \\ Izawa Takeshi*, Ohno Yosuke*, Yamamoto Shiro*, Kodaira Maria*, So Kunio*, \\ Shima Yuki*, Hayashi Yukio***, Kuwahara Katsuhisa**** and Kobayashi Kihei*** \\ *Department of Gnatho-Oral Prosthetic Rehabilitation, Nihon University School of Dentistry at Matsudo \\ ${ }^{* *}$ Institute of Oral Science, Nihon University School of Dentistry at Matsudo \\ *** Nihon University Graduate School of Dentistry at Matsudo
}

J Jpn Prosthodont Soc $51: 572-581,2007$

\section{ABSTRACT}

Purpose : The purpose of this study was to analyze the difference in educational effect on students who experienced both lecture-based learning (LBL) and problem-based learning (PBL) in a complete denture course. The analysis focused on differences between the two methods concerning self study, ability to understand clinical inference, and appraisal of class contents and tutors.

Methods : In the complete denture preclinical course, the class of 2003 received LBL in 3rd grade and PBL in 4th grade. PBL was planned to present five cases in five consecutive classes. Group discussion was carried out for each case, and a summary was required to be produced two times as a group, two times as an individual report and one time by group presentation.

A questionnaire regarding the educational effect of LBL and PBL and assessment of tutors was administered. Factor analysis was carried out to classify the questionnaire items and each item was analyzed between LBL and PBL (Paired-t test).

Results : Factor analysis revealed that the questionnaire items could be classified into four components. Comparing lecture type and PBL : "study attitude" (4 out of 7 items), "clinical inference ability" (all items), "class contents" (5 out of 7 items) and "tutor appraisal" (2 out of 5 items) showed significant assessment with PBL. Eighteen of 27 items (66.6\%) indicated the significant usefulness of PBL.

Conclusion : PBL improves the educational effect of self study and clinical inference ability, in comparison with LBL. However, since students are passive about taking the same system class repeatedly, a strategy to improve their attitude needs to be considered.

\section{Key words}

PBL, clinical inference, group discussion, SOAP, dental prosthetic education 